\title{
Jewish Ethics Regarding Refugees: Ideology and Realization
}

\author{
Tsuriel Rashi \\ Senior Lecturer, School of Communication, Ariel University, Israel
}

(Received 2 July 2020; revised 22 June 2021; accepted 22 June 2021)

\begin{abstract}
This article addresses the Jewish ethical approach to refugees. According to Jewish ethics, help must be offered to refugees of a foreign people, and sometimes, for the sake of peace, even to those of an enemy state. Reviewing the Jewish sources, I conclude that from an ethical point of view, preference should be given to refugees who are near the border over those from farther away. Priority must be given to those in acute distress who lack the basic items of sustenance. Sometimes there is a special value in finding a way to assist even one's enemies in the hope that such help will break down the barriers of hatred. Similarly, it is ethically preferable to offer help to blameless children over adults, whose intentions might be suspect.
\end{abstract}

Keywords: ethics; Judaism; refugees; dignity; freedom

This article addresses the Jewish ethical approach to refugees. ${ }^{1}$ While scholars have addressed the treatment of various foreigners or migrants in the biblical literature, little attention has been given to the specific category of refugees in Jewish thought. Drawing

\footnotetext{
${ }^{1}$ The contemporary understanding of the category of refugee is significantly influenced by the central instrument of international law on the subject, the 1951 Convention Relating to the Status of Refugees. Pursuant to the 1951 Convention, a refugee is defined as "any person who . . . As a result of events occurring before 1 January 1951 and owing to well-founded fear of being persecuted for reasons of race, religion, nationality, membership of a particular social group or political opinion, is outside the country of his nationality and is unable or, owing to such fear, is unwilling to avail himself of the protection of that country; or who, not having a nationality and being outside the country of his former habitual residence as a result of such events, is unable or, owing to such fear, is unwilling to return to it." Convention Relating to the Status of Refugees, July 28, 1951, 189 U.N.T.S. 137. Further on, the convention highlights the prohibition against expelling a person defined as a refugee, a prohibition that is hedged with various limitations:
}

Article 33. Prohibition of Expulsion or Return ("Refoulement”)

1. No Contracting State shall expel or return ("refouler") a refugee in any manner whatsoever to the frontiers of territories where his life or freedom would be threatened on account of his race, religion, nationality, membership of a particular social group or political opinion.

2. The benefit of the present provision may not, however, be claimed by a refugee whom there are reasonable grounds for regarding as a danger to the security of the country in which he is, or who, having been convicted by a final judgment of a particularly serious crime, constitutes a danger to the community of that country.

I base my analysis and discussion on an understanding of the refugee broader than the definition of the 1951 Convention-perhaps something akin to what Alexander Betts calls a "survival migrant." Alexander Betts, Survival Migration: Failed Governance and the Crisis of Displacement (Ithaca: Cornell University Press, 2013). Although there is a major distinction in today's refugee law between refugees and individuals whose immigration is driven by economic constraint, I do not draw that distinction here. I also note that international refugee law does not allow discrimination on the basis of nationality, as does Jewish law (although Israeli law does not). International refugee law allows exclusion of persons who themselves pose a security risk.

(c) The Author(s), 2021. Published by Cambridge University Press on behalf of the Center for the Study of Law and Religion at Emory University. This is an Open Access article, distributed under the terms of the Creative Commons Attribution licence (http:// creativecommons.org/licenses/by/4.0/), which permits unrestricted re-use, distribution, and reproduction in any medium, provided the original work is properly cited. 
on the Jewish tradition's concern for humanity and an analogy between the treatment of the slave and the treatment of the refugee in Jewish law and ethics, I address the category of refugee directly. According to Jewish ethics, help must be offered to refugees of a foreign people, and sometimes even to those of an enemy state for the sake of peace. Reviewing the sources, I conclude that from an ethical point of view, preference should be given to refugees who are near the border over those from further away. Priority must be given to those in acute distress without the basic items of sustenance. Sometimes there is a special value in finding a way to assist one's enemies, for it is hoped that such help will break down the barriers of hatred. Similarly, ethically it is preferable to offer help to blameless children over adults, whose intentions might be suspect.

\section{The Status of Refugees Today}

The discussion that follows is based in part on the work of Alexandros Paraskevas, Maureen Brookes, and Levent Altinay. ${ }^{2}$ Academic research on refugees has focused primarily on the vulnerability of refugees during their journey to a new home. ${ }^{3}$ There is also a considerable body of research about refugees being accepted into a host country, their integration, and their impact on those countries and their host communities. ${ }^{4}$ In the vast majority of refugeeproducing events after the Second World War, the overwhelming number of refugees has been hosted in low- and middle-income countries. Since then, such countries continued to take in the majority of refugees, and recent tendencies among the wealthier countries to raise barriers or even close their borders to refugees have only exacerbated this trend. Germany, for example, which hosts the most refugees and asylum seekers among the countries classified as high income, accepted only a hundred thousand refugees in 2020, raising the total number of displaced people within its borders to 1.2 million. Comparatively, Turkey, which is an upper-middle income country, ${ }^{5}$ has absorbed 3.7 million refugees; and Uganda, classified as a low-income country by the World Bank, has taken in 1.4 million. Lebanon, hosting nine hundred thousand refugees, has the highest ratio of refugees to its total population: one in five. ${ }^{6}$ Consequently, the protection of unwanted refugees requires more coordinated and effective integration policies and processes. ${ }^{7}$ All these scholars have

\footnotetext{
${ }^{2}$ Alexandros Paraskevas, Maureen Brookes, and Levent Altinay, "Global Refugee Crisis and the Service Industries," Service Industries Journal, 39 nos. 9-10 (2019): 663-67. See also, the text of the 1951 UN Convention above in footnote 1.

${ }^{3}$ Peter Browne, The Longest Journey: Resettling Refugees from Africa (Sydney: UNSW Press, 2006); Michael Collyer, "Stranded Migrants and the Fragmented Journey," Journal of Refugee Studies 23, no. 3 (2010): 273-93; Khalid Koser, “Asylum Policies, Trafficking and Vulnerability," International Migration 38, no. 3 (2000): 91-111.

${ }^{4}$ Jennifer Alix-Garcia and David Saah, "The Effect of Refugee Inflows on Host Communities: Evidence from Tanzania," World Bank Economic Review 24, no. 1 (2010): 148-70; Javier E. Baez, "Civil Wars beyond their Borders: The Human Capital and Health Consequences of Hosting Refugees," Journal of Development Economics 96, no. 2 (2011): 391-408; Ximena V. Del Carpio and Mathis Wagner, "The Impact of Syrian Refugees on the Turkish Labor Market," Policy Research Working Paper 7402 (Washington, DC: World Bank Group, 2015); James C. Hathaway, The Rights of Refugees under International Law (Cambridge: Cambridge University Press, 2005); James C. Hathaway, "Refugees and Asylum," in Foundations of International Migration Law, ed. Brian Opeskin, Richard Perruchoud, and Jillyanne Redpath-Cross (Cambridge: Cambridge University Press, 2012), 177-204; James C. Hathaway and Hugo Storey, "What Is the Meaning of State Protection in Refugee Law? A Debate," International Journal of Refugee Law 28, no. 3 (2016): 480-92; Guy S. Goodwin-Gill and Jane McAdam, The Refugee in International Law, 3rd ed. (Oxford: Oxford University Press, 2007); Deborah Anker and Josh Vittor, "International Human Rights and US Refugee Law: Synergies and Contradictions," in Human Rights and the Refugee Definition: Comparative Legal Practice and Theory, ed. Bruce Burson and David James Cantor (Leiden: Brill Nijhoff, 2016), 109-37; Leah Zamore and Alex Aleinikoff, The Arc of Protection: Toward a New International Refugee Regime (Stanford: Stanford University Press, 2019).

5 “World Bank Country and Lending Groups," World Bank, accessed July 29, 2021, https://datahelpdesk.worldbank. org/knowledgebase/articles/906519-world-bank-country-and-lending-groups.

${ }^{6}$ UNHCR, Global Trends: Forced Displacement in 2020 (Copenhagen: United Nations High Commissioner for Refugees, 2021).

${ }^{7}$ Rainer Bauböck, "Refugee Protection and Burden-Sharing in the European Union," Journal of Common Market Studies 56, no. 1 (2018): 141-56, at 148; see also Peter Slominski and Florian Trauner, "How Do Member States Return Unwanted Migrants? The Strategic (non-)use of 'Europe' during the Migration Crisis," Journal of Common
} 
obscured-in one way or another-the public and ethical dilemmas in connection with the proper relationship between the host country and the refugees flocking to it en masse. They have been less concerned with the proper treatment of the individual refugee and ignored or have been indifferent to the religious roots of the ethical reference: How to balance the human obligations to care for "others" fleeing for their lives or to improve their destinies with concern for the citizens of the host country and their civil rights.

Refugees from third-world countries have been coming to Western Europe, the United States, and Australia, giving rise to public debates in many countries concerning the ethical aspects of the approach toward refugees and how to treat them: whether to settle them in the host country and grant them full citizenship, return them to their own native lands, or provide various resources in refugee camps elsewhere. Naturally, there is ethical significance to such questions, and that has been discussed in many forums. ${ }^{8}$ Some of the discourse has addressed the theological and ethical questions from Christian and Muslim perspectives, ${ }^{9}$ but there have been few discussions in connection with Jewish theological and ethical aspects related to this issue. ${ }^{10}$ In this article I focus on the ethical aspect as mandated by Jewish tradition regarding the status of "the other," refugees, and the religious and ethical justifications to assist them in various ways. These justifications developed throughout the rich history of Jewish religious literature, which began when a nation of slaves left Egypt more than three thousand years ago and started to formulate its worldview toward the weak and the foreign.

\section{The Historical Development of the Written and Oral Jewish Law}

According to Jewish tradition, the Ten Commandments were given to Moses at Mount Sinai some three thousand years ago in the presence of the entire Israelite nation (six hundred thousand adult males). The complete Torah, written by Moses toward the end of his life, includes 613 commandments.

Market Studies 56, no. 1 (2018): 101-18; Marie Wolf and Marinus Ossewaarde, "The Political Vision of Europe during the 'Refugee Crisis': Missing Common Ground for Integration,” Journal of European Integration 40, no. 1 (2018): 33-50; Paraskevas, Brookes, and Altinay, "Global Refugee Crisis and the Service Industries."

${ }^{8}$ Serena Parekh, Refugees and the Ethics of Forced Displacement (London: Taylor \& Francis, 2016); Christopher Heath Wellman and Phillip Cole, Debating the Ethics of Immigration (New York: Oxford University Press, 2011); Matthew J. Gibney, The Ethics and Politics of Asylum (Cambridge: Cambridge University Press, 2004); Matthew J. Gibney, "The Ethics of Refugees," Philosophy Compass 13, no. 10 (2018): e12521, https://doi.org/10.1111/phc3.12521; Phil Orchard, A Right to Flee: Refugees, States, and the Construction of International Cooperation (Cambridge: Cambridge University Press, 2014); Megan Bradley, "Unresolved and Unresolvable? Tensions in the Refugee Regime," Ethics \& International Affairs 33, no. 1 (2019): 45-56; Tina (A. C.) Besley and Michael A. Peters, "The Refugee Crisis and the Right to Political Asylum," chap. 9 in Teaching, Responsibility, and the Corruption of Youth (Leiden: Brill, 2019).

${ }^{9}$ On Christian perspectives, see, for example, Luke Bretherton, "The Duty of Care to Refugees, Christian Cosmopolitanism, and the Hallowing of Bare Life," Studies in Christian Ethics 19, no. 1 (2006): 39-61; Kristin E. Heyer, "Radical Solidarity: Migration as Challenge for Contemporary Christian Ethics," Journal of Catholic Social Thought 14, no. 1 (2017): 87-104; Fleur S. Houston, You Shall Love the Stranger as Yourself: The Bible, Refugees, and Asylum (New York: Routledge, 2015); Alexander Unser and Hans-Georg Ziebertz, "The Impact of Religion and National Origin on Attitudes towards Refugee Rights: an International Comparative Empirical Study," Religions 11, no. 6 (2020), article 303, https://doi.org/10.3390/rel11060303. On Muslim perspectives, see, for example, Zeki Saritoprak, "The Qur'anic Perspective on Immigrants: Prophet Muhammad's Migration and Its Implications in Our Modern Society," Journal of Scriptural Reasoning 10, no. 1 (2011), https://jsr.shanti.virginia.edu/back-issues/vol-10-no-1august-2011-people-and-places/the-quranic-perspective-on-immigrants/; Ahmad Badri Abdullah, "Reimagining Islamic Ethics in Contemporary International Relations," Islam and Civilisational Renewal 6, no. 3, (2015): 418-21; Vincent Chetail, ed., "Asylum and Islam," special issue, Refugee Survey Quarterly 27, no. 2 (2008). On religious ethics and refugees generally, see David Hollenbach, Humanity in Crisis: Ethical and Religious Responses to Refugees (Washington, DC: Georgetown University Press, 2019).

${ }^{10}$ David Patterson, “A Jewish Perspective on Ethical Issues Surrounding the Refugee Strangers,” Cross Currents 67, no. 3 (2017): 612-22; Gil Ribak, "Helpless Refugees or the Seed of Amalek: A Cautionary Note about the Use of Judaism as a Means to Justify Political Agendas," Cross Currents 67, no. 3 (2017): 555-64. 
Around these commandments and accompanying elaborations and clarifications (written law) there evolved an oral law comprising rabbinic discussions and arguments over the ensuing centuries that ultimately coalesced into Jewish law and jurisprudence-the halakhah. In the second century $\mathrm{CE}$, the period in which the first major codification of Jewish law, the Mishnah, was written, rabbis set up a major center of scholarly religious learning to facilitate continuation of the halakhic tradition.

In the ensuing eighteen centuries, generations of religious leaders living in many countries around the world under the influence of various religiously oriented civilizations (primarily Catholic, Eastern Orthodox, Muslim, and Protestant) continued to broaden and further clarify and codify the halakhah, a praxis-based code of law (that is, legal principles are derived from specific problems and issues that arise in daily life, much like English Common Law). Thus, during the past fifteen hundred years, tens of thousands of commonman questions and local rabbinical answers (shut) have clarified the halakhah, thereby developing what has come to be called responsa literature. Every so often, because of the unwieldiness of such a large corpus, major rabbinical commentators have taken it upon themselves to codify the law in some systematic and quasi-authoritative fashion. ${ }^{11}$

In these commentaries, one can distinguish between two ways of developing an ethical code: (1) formulating instructions regarding the proper conduct of a community and (2) providing an in-depth examination to discern the implicit code of ethics of a professional body as it appears in its binding sources. The second is the approach, for example, that governs instructions issued in a security organization or the protocols of a medical organization that reflect an ethical worldview. In the context of Jewish ethics, it is possible to explore the ethical guidelines-the ideas and norms-that can be found in the binding literature of the professional community. I therefore explored the ethical imperative toward refugees by examining the corpus of halakhic literature, analyzing the sources that deal with the essence of proper conduct in order to elucidate the values reflected in the halakhic texts. The Jewish ethical approach, which is informed by Jewish law, is open to receiving refugees and encourages the host country to treat them well. This approach is justified by three independent arguments: (1) the importance of life; (2) on analogy with slavery and the appropriate way of taking care of the "other"; and (3) for the sake of peace. Although any one of these arguments might be compelling, all of them taken together provide evidence of the comprehensive approach to refugees in Jewish tradition.

\section{The Importance of Life}

The serious prohibition against spilling blood underlies human moral awareness. The response and complaint of Cain that he is not his brother's keeper (Genesis 4:9) ${ }^{12}$ called forth the harsh query: "What have you done? The voice of your brother's blood is crying to me from the ground" (Genesis 4:10). In the Midrash, Rabbi Nathan adds: "This teaches us that the blood of his children, grandchildren and all his descendants to the end of time were present and shouting to G-d. This tells us that one person is equal to the entire Creation." ${ }^{13}$ Thus, as soon as Noah emerged from the Ark, the entire human species was forcefully and sternly commanded to take care not to do harm: "Whoever sheds the blood of man, by man shall his blood be shed, for G-d made man in his own image" (Genesis 9:6).

\footnotetext{
${ }^{11}$ Tsuriel Rashi, "Media Credibility and its Reflection in Jewish Responsa from the Eighteenth to the Twenty-First Century," Journal of Communication and Religion 35, no. 2 (2012): 96-109. For a comprehensive survey of the development of the written law and oral law, see Menachem Elon, Jewish Law: History, Sources, Principles/Ha-Mishpat Ha-Ivri, trans. Bernard Auerbach and Melvin J. Sykes, 4 vols. (Philadelphia: Jewish Publication Society, 1994).

${ }^{12}$ All translations of biblical and other original Hebrew sources in this article are my own. For readers who would like to explore these sources in English translation, I offer suggestions of available translations. For biblical passages, see Harold Fisch, trans., The Koren Tanakh (Jerusalem: Koren, 2016).

${ }^{13}$ Judah Goldin, trans., The Fathers: According to Rabbi Nathan (New Haven: Yale University Press, 1955), chap. 31, at 126. For an extensive discussion of the universal message referred to here and in the other Talmudic parallels, see note 17 below.
} 
Rabbi Meir (second century CE) affirmed the dual import of this command, wherein there is not just a warning against doing harm but also an emphasis on the value of saving: "Therefore man was created alone in the world, to teach us that anyone who destroys a single soul is as though he destroyed a whole world... And anyone who saves a single soul is as though he maintained the whole world" (Mishnah, Sanhedrin 4:5). ${ }^{14}$

Maimonides wrote that because of the uniqueness of each person and the unique trajectory of his life, he is considered a whole world: "All the inhabitants of the world are created in the image of Adam, the first man, and yet no one person's face resembles the face of his colleague. Therefore, each person can say: 'The world was created for me"' (Mishneh Torah, Book of Judges, 12:3). ${ }^{15}$ The decisive acknowledgment in the Mishnah of the singularity of each person made it the source of inspiration for the principles of individualism in eighteenth-century liberalism. Today, too, the Mishnah affirms not just the rights that each individual is born with but also the obligation incumbent upon every human being to reach out to his fellow man to save him in his hour of distress. ${ }^{16}$ Every individual, including a refugee, is a unique human being.

Love of one's fellow that leads someone to share in another's pain and to come to the other's aid is one of the values espoused by Judaism. The zenith of love of one's fellow is expressed in "he who saves one life saves a whole world" (Mishnah, Sanhedrin 4:5). ${ }^{17}$

\footnotetext{
${ }^{14}$ As noted above, my translation of the Mishnah. For a translation of the Mishnah, see Jacob Neusner, trans., The Mishnah: A New Translation (New Haven: Yale University Press, 1988).

${ }^{15}$ As noted above, my translation of Maimonides. For a translation of Maimonides, see Herbert Danby, trans., The Code of Maimonides (Mishneh Torah) (New Haven: Yale University Press, 1949).

${ }^{16}$ The duty to rescue is, of course, much more complicated. In Israel, the 1999 law "You will not stand on the blood of a neighbor" (based on Leviticus 19:16 as interpreted in the Babylonian Talmud, Sanhedrin 73A) was enacted following a private member's bill by MK Hanan Porat. When it was brought to a final vote, MK Porat justified his initiative:
}

We would not need this law if we really were in a situation where the natural morality, according to which a person who sees another person in distress before his eyes would not hesitate, would take and interest, and assist, even if it cost him a lot of money and if it puts him at risk. We thought, however, because of very unfortunate cases in recent years and in light of the desire to establish a norm that anchored in Jewish morality, based on "you will not stand on the blood of a neighbor," that one cannot stand aside when one sees a person in danger: A Jew or Gentile, an adult or a minor, a man or a woman, one must reach out to him and save him.

DK, 14th Knesset, Session No. 218 (1998) (Isr.) (my translation). Because of its uniqueness-the imposition of a duty to do, which is fundamentally a moral stance-the law was enacted separately from the Penal Code. The law not only identifies what is forbidden but also explains the right thing to do. It is common to see the scope of the duty it imposes as minimal: a mandate to help one another and a notification to the authorities to assist wherever and whenever they are asked. Such laws are common in Europe, but they are rarely found in the Anglo-American legal tradition. In the European tradition they are attributed to Judeo-Christian ethics and are known as Good Samaritan Laws, after a parable in the Gospel according to Luke: two men ignored a man who had fallen victim to theft and violence, but the Good Samaritan took care of him (Luke 10:25-37). The obligation to rescue is not found in English law. In the United States, the obligation does not exist in most states, although many laws encourage rescue and provide immunity, relief, and compensation to the rescuer. However, in Vermont, Minnesota, Rhode Island, and Wisconsin, the rescue obligation was established in response to public pressure following rape cases in which witnesses did not intercede. For more on the importance of the individual's life and the balances required in regard to saving the individual and the many from an ethical and Jewish point of view, see Rashi Tsuriel, "When the Arrow Precedes the Trolley: Jewish Perspectives on the Trolley Dilemma," Philosophia 46, no. 1 (2018): 193-206. For further discussion, see Quentin Skinner, Liberty before Liberalism (Cambridge: Cambridge University Press, 1998); John Dunn, The Political Thought of John Locke: An Historical Account of the Argument of the "Two Treatises of Government" (London: Cambridge University Press, 1969).

${ }^{17}$ The text in the Kaufman Manuscript, the Parma Manuscript of the Mishnah, and printed versions of the Jerusalem Talmud does not include the words (in Hebrew) "from Israel." In various manuscripts and printed versions of the Babylonian Talmud and the printed versions of the Mishnah, the words "from Israel" appear, and the sentence (in translation) reads: "he who saves one life from Israel saves a whole world." In his Mishneh Torah, Maimonides quotes a version of the Mishnah in which the word "Israel" is replaced by "in the world" (the manuscript of Yah. Ms. Heb. 2.), and in most versions, "from Israel" does not appear, but there is one that 
Thus, it is altogether right and proper to volunteer to help an individual in distress and certainly to offer aid to a group of suffering people, including the refugee and refugee communities more broadly. Such help is an expression of the attributes of mercy and peace, which are characteristics ascribed to G-d and to which a person should aspire.

\section{The Distinction between and Analogy of Slaves and Refugees in the Jewish Tradition}

\section{The Exodus from Egypt as a Formative Ethos}

Of further importance to the Jewish tradition, the Bible demands that sensitivity be shown toward the weaker sectors within the society, which included slaves, an ethos stemming from the hundreds of years that the Jewish people were enslaved in Egypt, as described in Exodus. As they began their way toward nationhood as newly freed slaves, the Jews could not ignore the fate of slaves within their community. In light of this history, the contemporary Jewish community cannot remain indifferent to the treatment of the weak in every civil society on a national or a global level.

The years of slavery in Egypt with its suffering and hard labor and the Exodus from that land gave rise to the collective identity of Judaism. The Torah uses these memories to explain some of the commandments and to encourage Jews to perform them:

You shall not pervert the justice due to the sojourner ${ }^{[18]}$ or to the fatherless or take a widow's garment in pledge. But you shall remember that you were a slave in Egypt and the Lord your G-d redeemed you from there; therefore, I command you to do this . . . When you beat your olive trees, you shall not go over them again. It shall be for the sojourner, the fatherless, and the widow. When you gather the grapes of your vineyard, you shall not strip it afterward. It shall be for the sojourner, the fatherless, and the widow. You shall remember that you were a slave in the land of Egypt; therefore, I command you to do this. (Deuteronomy 24:17-22)

reads "he who saves one life from Israel saves a whole world."

The absence or presence of the words "from Israel" has provoked lengthy discussions. Is it a humanistic statement, which attaches importance to the life of each and every person created in the image of God, or is it a national statement, which attaches importance only to the life of a person from Israel (i.e., a Jew). This discussion is always preceded by the question about the wording of the original version, and whether it is possible that the variations are distortions created over the years. The late Ephraim Elimelech Urbach, a professor of Talmud at the Hebrew University of Jerusalem and the president of the Israel Academy of Sciences and Humanities, presented a clear position on this issue:

reading the article in the Mishnah in its entirety ... points in the direction of the wording that does not include "from Israel," since it is a conclusion about the importance of human life from the fact that the first man was created alone. . However, the Mishnah answers the question "how do you interrogate witnesses." These witnesses were from Israel and they came to testify about one Jew who murdered another Jew. A distinction must therefore be made between utilizing the text to teach morality and its use in interrogating witnesses. (Mishnah, Sanhedrin 4:5)

For further elaboration of Urbach's argument, see Ephraim E. Urbach, "Kol Ha-meqayyem Nefesh Ahat . . . : Development of the Version, Vicissitudes of Censorship, and Business Manipulations of Printers," Tarbiz 3 (1971): 268-74 (in Hebrew).

${ }^{18}$ It should be noted that there are three categories of stranger in the Biblical language-ger, nokhri, and zarwhich may be significant for the ethical demand regarding the stranger in Jewish teaching. The ger is a resident, a part of the community; the nokhri is a foreigner who might become part of the community; and the zar is an alien who might pose a danger to the community. Neither the ger nor the nokhri, in principle, would try to undermine the community in which he or she lives. For more on this matter, see Eliezer Hadad, The Status of Minorities in the Jewish State: Halakhic Aspects (Jerusalem: Israel Democracy Institute, 2010) (in Hebrew); Eliezer Hadad, Human Dignity and the Divine Image: Equality and Difference (Jerusalem: Israel Democracy Institute, 2019) (in Hebrew). 
The obligation to look after the weak and distressed elements of society is supported by the moral argument: You, too, were there. You-a Jew charged with following mitzvot (commandments) - certainly understand the nature of suffering and can identify one who is in that state. You were saved by G-d's kindness and so are obliged to act with sensitivity and concern. For that reason, G-d took you out of Egypt, and therefore you have been commanded, "Remember that you were a slave in the land of Egypt" (Deuteronomy 5:15). This argument adds to the current literature on the ethical imperative toward refugees. While others have written about biblical injunctions regarding the sojourner, the term sojourner does not really describe a refugee; rather, it describes various kinds of migrants. The discussion of slavery in the Jewish tradition, however, provides an analogy for duties to the refugee.

\section{Slavery in the Jewish Tradition}

The Torah includes many commandments regarding relationships between one person and another. In all of these mitzvoth is the aspiration for law and moral justice, equal rights, and love for others, found throughout the Torah, as in the verse "and love your neighbor as yourself" (Leviticus, 19:18). Many times, the Torah mandates the proper treatment of people who are humble, poor, or oppressed. It might seem puzzling, then, that the Torah also addresses the status of slaves, provides laws about selling people, and permits the institutional discrimination among peoples, as in the verse: "Both thy bondmen and thy bondmaids, which thou shalt have, shall be of the heathen that are round about you; of them shall ye buy bondmen and bondmaids" (Leviticus 25:44).

One of the principles that characterizes a modern society is the freedom of the individual. Societal structures such as feudalism and the practice of slavery are increasingly rejected as immoral by the global community, and the world is moving in the direction of equal rights. The Jewish people have always suffered from restrictions and an inferior status, so it may be difficult today to understand that the Bible could have mandated the treatment of slaves. However, the Bible's protective laws and system of rights pertaining to slaves and slavery reflect the prevailing reality of slavery in the ancient world. Jewish law permitted slavery, but it had to be tempered with some rights and protections. Thus, while the Bible anchored legal slavery-the slave is considered the master's property (Exodus 21)-it also demanded humane treatment: just as the master takes care of his property, so he must take care of the slave's well-being. Thus the Bible mandates respect for the basic human dignity of slaves and fairness toward them in general and especially prohibits returning a slave who escaped from a non-Jewish owner and has taken refuge with a Jewish lord for fear that the escaping slave would be harmed if returned to a non-Jewish master. This concern is expressed in a myriad of texts spanning Jewish history.

A Jew who was interested in acquiring slaves could not take them from another continent; transport them in a cattle-like cargo ship; or sell them at a slave market without giving them some rights and protection. Buying slaves does not allow the owner to treat them cruelly. Maimonides established the proper treatment of slaves:

It is permissible to have a Canaanite slave perform heavy labor. Although this is the law, the attribute of piety and the way of wisdom is for a person to be merciful and to pursue justice, not to make his slaves carry a heavy yoke, nor cause them distress. He should allow them to partake of all the food and drink he serves. This was the practice of the Sages of the first generations, who would give their slaves from every dish of which they themselves would partake. And they would provide food for their animals and slaves before partaking of their own meals . . And so, it is written in Psalms (123:2): "As the eyes of slaves to their master's hand, and like the eyes of a maid-servant to her mistress' hand, so are our eyes to G-d.

Similarly, we should not embarrass a slave by our deeds or with words, for the Torah prescribes that they perform service, not that they be humiliated. Nor should one shout or vent excessive anger upon them. Instead, one should speak to them gently and listen 
to their claims. This is explicitly stated with regard to the positive attributes of Job, for which he was praised (Job 31:13, 15): "Have I ever shunned justice for my slave and maid-servant when they quarreled with me... Did not He who made me in the belly make him? Was it not the One who prepared us in the womb?" Cruelty and arrogance are found only among idol-worshipping gentiles. By contrast, the descendants of Abraham our patriarch, that is, the Jews that the Holy One, blessed be He, granted the goodness of the Torah and commanded to observe righteous statutes and judgments, are merciful to all. Similarly, with regard to the attributes of the Holy One, blessed be He, which He commanded us to emulate, it is written, (Psalms 145:9) "His mercies are upon all of His works." And whoever shows mercy to others will have mercy shown to him, as implied, (Deuteronomy 13:18) "He will show you mercy and be merciful upon you and multiply you." (Mishneh Torah, Laws of Slaves 9:8)

Clearly, anyone who bought slaves took on a kind of burden. Owners had to consider every word that came out of their mouths when they spoke with their slaves and certainly had to consider their every act toward them.

In sum, while the Bible did not oppose slavery, it limited it. The post-exodus Jews owned slaves, but because of their experience as slaves in Egypt, they sought to temper the cruelty of slaveholding as an institution. The commandments concerning slavery are intended to prevent abuse in the relationships between human beings, between employees and employers, and between the strong and the oppressed. Slavery was uncomfortable to the biblical mind and the biblical laws were designed to counter indifference to the fate of a slave. The Bible dealt with the reality of slavery in the world and mandated the proper relationship between owner and slave based on seeing the slave as a human being who had basic rights and personal needs.

Moreover, Judaism did not only seek to make slavery more humane. The Jewish people, slaves in the land of Egypt, were eventually refugees from Egypt, where they had been treated cruelly. Thus, there is another dimension to the argument. Refugees are analogous to Jewish slaves in Jewish law: just as returning the Jews to Egypt would have meant returning them to practices of cruelty, persecution, and death, so would returning refugees to their country of origin. This analogy may be less commonly recognized, but at a minimum, in the commandments there is a clear obligation not to recreate practices of suffering. Just as Jews were not to have escaped Egypt only to become Egypt, receiving societies should not replicate the cruelties of the societies from which the refugees fled.

\section{Refugees in the Jewish Tradition}

The term refugee ( palit, appears for the first time in the book of Genesis, used for a man who has fled what might be considered the first world war-between the four and the five kings: "Then one who had escaped came and told Abram the Hebrew, who was living by the oaks of Mamre the Amorite, brother of Eshcol and of Aner. These were allies of Abram" (Genesis 14:13). The refugee seems to have been a survivor of the fighting who managed to escape death after all or most of his family and friends had died in the war. The sense of oppression and isolation is also expressed in another verse, where on the first of two occasions appears the phrase "survived or escaped" (sarid u-palit): "And the others came out from the city against them, so they were in the midst of Israel, some on this side, and some on that side. And Israel struck them down, until there was left none that survived or escaped" (Joshua 8:22). Similarly, the phrase "escaped the sword" ( plitey herev) appears in Ezekiel: "When you have among the nations some who escape the sword" (Ezekiel 6:8).

But what is the right attitude toward a refugee from war? To answer this question, one has to base the argument on the importance of life, the attitude toward slavery and the persecuted individual, and the status of the refugee who does not want to lose his life. 
Although the concept of refugee is acknowledged in biblical literature, there is no specific set of moral obligations for the treatment of refugees as refugees. Forced migration was a reality of the ancient world, but to develop an ethical perspective, one has to look to other frameworks, such as the laws regarding slaves. Further, there is a distinction between the sojourner and the refugee in terms of mandates regarding moral obligations.

\section{The Slave and the Refugee: The Prohibition on Returning Persons to Conditions of Suffering}

There are indeed real differences between refugees and slaves, but it is possible to see the modern refugee as a parallel to the slave of ancient times. While the essential difference is that no one owns the refugee, there essential similarity is both face danger. There was danger to the lives of slaves returned to cruel non-Jewish masters; modern refugees, many of whom are fleeing slaughter, are in danger of losing their lives if returned to their homeland. Whereas for refugees, freedom lies in getting out of their country, not in the Revelation at Mount Sinai, which defines freedom as understood in Judaism, they are equally destitute and without rights and status in the place they have reached.

In the Jewish historical context, it was precisely the years of slavery in Egypt that were a founding period. In more than a dozen places, the Bible speaks of the proper treatment of the weak in society and, as noted above, exhorts Jews to "Remember that you were a slave in the land of Egypt" (Deuteronomy 5:15). Thus, it is not unreasonable to draw an analogy between these two populations. Sometimes, the lot of both and the fate of both if returned to the place from where they had fled were the same. ${ }^{19}$ Persecution of a refugee falls under the biblical prohibition against returning a slave to his master: "You shall not give up to his master a slave who has escaped from his master to you. He shall dwell with you, in your midst, in the place that he shall choose within one of your towns, wherever it suits him. You shall not wrong him" (Deuteronomy 23:16). According to the plain meaning of the verse, if a slave has run away from his master in one of the neighboring countries and gone to the Land of Israel, it is forbidden to return him to his master. To complete the picture, I cite a similar verse in the Hebrew Bible: "Do not slander a servant to his master, lest he curse you, and you be held guilty" (Proverbs 30:10).

In his great philosophical work Moreh Nevuchim (The Guide for the Perplexed), Maimonides dealt with the proper relationship with a slave who has run away from his master:

The precepts contained in "the laws concerning slaves" (Hilkot abadim) likewise prescribe only acts of pity, mercy and kindness to the poor. It is an act of mercy to give liberty to a Canaanite servant for the loss of one of his limbs (Exod. xxi. 26, 27), in order that he should not suffer from slavery and illness at the same time. The law applies even to the case that a tooth of a slave has been knocked out, much more to the mutilation of other limbs... Mercy is also the object of the law, "Thou shalt not deliver unto his master the servant that is escaped from his master" (Deut. xxiii. 15); but it teaches besides a very useful lesson, namely, that we must always practice this virtue, help and protect those who seek our help, and not deliver them unto those from whom they flee; and it is not sufficient to give assistance to those who are in need of our help; we must look after their interests, be kind to them, and not hurt their feeling by words. Thus the Law says: "He shall dwell with thee, even among you, in that place which he shall choose in one of thy gates, where it liketh him best: thou shalt not vex him" (ibid. ver. 16). This we owe to the lowest among men, to the slave; how much more must we do our duty to the freeborn, when they seek our assistance ${ }^{20}$

\footnotetext{
${ }^{19}$ Yogita Goyal, "The Logic of Analogy: Slavery and the Contemporary Refugee," Humanity: An International Journal of Human Rights, Humanitarianism, and Development 8, no. 3 (2017): 543-46.

${ }^{20}$ Moses Maimonides, The Guide for the Perplexed, trans. Michael Friedlander, 4th rev. ed. (New York: E. P. Dutton, 1904), 341.
} 
Maimonides saw the historical collective memory of the Jewish people, who began their national history as a nation of the slaves and so were shaped by the experience of slavery in Egypt, as mandating that every individual must be treated with compassion and mercy. This is also true of those who have fled a place where they were in constant danger of life and in a state of existential anxiety about their fate.

\section{The Slave and the Refugee: Supporting Those Who Flee}

Apart from addressing the refugees' freedom and rescuing him from death, one also has to deal with their quality of life with concern and responsibility. Various scholars have discussed the issues involved in host countries accepting refugees. ${ }^{21}$ The two aspects of the analogy between the biblical slave and the modern refugee are as follows: The refugee is like the slave who has fled his cruel master and, therefore, like the Jews who fled Egypt. The refugee is also like the slave in Jewish society and must be treated well. Unlike the slave in Jewish society, the refugee is not expected to be subservient to the host society; the analogy focuses on the distress of those who have escaped and cannot return to whence they came. The moral expectation is to give them the support that they need to survive and thrive in their new surroundings. The Midrash teaches the value of human dignity and the attitude toward slaves through the story of one of the sages of Babylonia, who lived at the end of the second century CE: "The wife of Rabbi Issi argued with her slave girl, and Rabbi Issi reprimanded her about this in front of the slave girl. She said to him: Why do you shame me in front of my slave girl? He replied: Did not Job say, 'If I have rejected the cause of my manservant or my maidservant. . . And what then shall I do when G-d rises up? When he makes inquiry, what shall I answer him?' (Job 31:13)."22

In his commentary on scripture, the Malbim (Rabbi Meir Leibush) a nineteenth-century Romanian rabbi, emphasized the ethical aspect of the prohibition against exploiting the slave. Basing himself on Sifre, ${ }^{23}$ a halakhic Midrash on Deuteronomy that allows a slave to settle anywhere "he chooses," as he wishes, Malbim explained that the reason was that the slave could live "where he will have a livelihood, where he will be able to maintain himself" (Deuteronomy 23:17). It follows that the concern for a slave who has run away from his owner is not derived from the idea of fleeing to a city of refuge, but from the obligation to sustain the slave and to help him find a life of livelihood and dignity. Just as these things are true in relation to slaves who escaped from their masters, it should also be so in relation to refugees who escape from those who wish to kill them in their native countries. A refugee is entitled not only to charity, but also to justice. Moreover, an element of this justice, similar to the obligation toward the poor, is that one will be able to work and earn a living.

Sifre also interprets the end of the passage: ["he will settle among you, in a place of his choosing] that is good for him"-from somewhere bad to somewhere beautiful. According to Malbim, this midrash ordains a constant effort to improve the refugee's situation and not to be satisfied with doing the minimum, "People when they come to another country tend to settle where a livelihood is available but where the place does not suit them. And after they have settled where work can be found, they will look around for a place that suits them better, which will be truly good" (Deuteronomy 23:17). That is why Sifre states: "From a bad home to a beautiful one."

\footnotetext{
${ }^{21}$ Alastair Ager and Alison Strang, "Understanding Integration: A Conceptual Framework," Journal of Refugee Studies 21, no. 2 (2008): 166-91; Marko Valenta and Nihad Bunar, "State Assisted Integration: Refugee Integration Policies in Scandinavian Welfare States: The Swedish and Norwegian Experience," Journal of Refugee Studies 23, no. 4 (2010): 463-83; Jenny Phillimore, "Refugees, Acculturation Strategies, Stress and Integration," Journal of Social Policy 40, no. 3 (2011): 575-93.

${ }^{22}$ H. Freedman and Maurice Simon, trans., Midrash Rabbah: Genesis, vol. 1, Parsha 48 (London: Soncino Press, 1983).

${ }^{23}$ Marty Jafee, trans., Sifre Devarim (Seattle: University of Washington Stroum Center for Religious Studies, 2016), Pisqa' 259, https://jewishstudies.washington.edu/book/sifre-devarim/chapter/pisqa-259/.

${ }^{24}$ Jaffee, Sifre Devarim, Pisqa' 259.
} 
The biblical injunction "Do not oppress him" (Deuteronomy 23:17) is interpreted in the halakhic midrash, Sifre Deuteronomy, as the obligation to preserve the slave-refugee's dignity and his ability to earn a livelihood in a dignified way, and not just to concern oneself with his freedom. The requirement here is to emphasize the prohibition against embarrassing a person and causing him to lose his dignity. According to Malbim, "After someone who had been a slave and escaped and arrives among Jews and settles where a livelihood is available, even if he changed his home for something good, people will say: 'Did you see this slave, how he lords it over us?' And on this it is said: 'Do not oppress,' even with words" (Deuteronomy 23:17).

There is a complete Torah of a slave's dignity and freedom that is concerned with not only the refugees' physical well-being but also their self-esteem and their position in the eyes of the community that takes them in. The great challenge in view of this moral requirement to support those who flee is when the host country is required to accept refugees who come from an enemy state.

\section{Assistance to Enemies}

A possible obstacle to help for refugees is that they may be from an enemy country or a terror organization. Some certainly hate the country to which they arrive, and it is possible that they were, are, or will be a danger to the host country and its inhabitants. Is help to such people right? If it is not right, perhaps it is forbidden?

In scripture, the prophet of Ahab rebukes the king of Israel for his act of kindness in making a peace treaty with the king of Aram: "You have set free a man I had determined should die by your hand. Therefore, it is your life for his life, your people for his people" (1 Kings 20:42).

The obligation not to act mercifully in circumstances that require cruelty is hinted at in the Torah (Deuteronomy 13:9-10, 19:13) and is stated explicitly by the sages. ${ }^{25}$ Primarily, the warning is against faulty ethical judgment: "Rabbi Shimon ben Lakish said: Anyone who is merciful when he should be cruel, in the end will be cruel where he should have been merciful" (Ecclesiastes Rabbah 7:16). This is explained in books dealing with Jewish philosophy; it is also mentioned in halakhic texts. Mercy for evil people is likely to lead to harm and damage to the innocent, so, clearly, mercy should not be offered to enemies and criminals.

An alternative perspective is found in some of the explanations of the verse: "If your enemy is hungry, give him bread to eat, and if he is thirsty, give him water to drink. For you will heap burning coals on his head, and the Lord will reward you" (Proverbs 25:2122). Behind this injunction is perhaps the ideal of remedying wicked behavioral traits or eradicating hatred. As the sage Ben Zoma said at the beginning of the second century CE: "Who is it that is most mighty? One who subdues his evil impulse. ..," to which Rabbi Nathan adds, "(Mighty is he) who makes of his enemy a friend."26 It is possible that the difference in the two perspectives is that one condones necessary cruelty in time of war and the other calls for empathy and compassion even for the enemy-the wish to change and repair the world.

In practice, to avoid getting into an uncertain situation if one helps evildoers and the enemy, assistance might be directed to children. One should not make an assumption about what a child will be when he or she grows up, even if that child will be raised in an environment that cultivates hatred. The Talmud quotes a Jewish scholar from $300 \mathrm{CE}$ who claimed that a person should not be judged on what he will become but as he is at that time: "And Rabbi Yitzhak said: A person is only judged by his actions at that time, as it is said 'for God has heard the voice of the boy where he is"' (Genesis 21:17). ${ }^{27}$ As Rabbi Shlomo Yitzhaki (Rashi), the great Talmud commentator in eleventh-century France,

\footnotetext{
${ }^{25}$ Jaffe, Sifre Devarim, Pisqa' 89, https://jewishstudies.washington.edu/book/sifre-devarim/chapter/pisqa-89/.

${ }^{26}$ Goldin, The Fathers According to Rabbi Nathan, 101.

${ }^{27}$ Babylonian Talmud, Rosh Hashana 16b. As noted above, all translations from the Talmud are mine. For a translation of the Talmud, see Schottenstein Edition Talmud Bavli (Brooklyn: Mesorah Publications, 1990-2012).
} 
explained, this is said even if the one in need is likely in the future to become evil and to harm others.

\section{For the Sake of Peace and Repairing the World}

It is not sufficient to rely just on the concern of one individual for another, such as a private person who meets a runaway slave; rather we have to talk about what is required and expected of the collective that encounters another collective in distress. Concern for people in distress and efforts to help them are norms in civilized societies around the globe. Across the world today there are many organizations whose declared purpose is to bring peace between peoples and help the disadvantaged elements of humanity. In the Jewish world, this is known as darkei shalom (for the sake of peace). The concept of darkei shalom refers to the range of laws governing the behavior of human beings with their fellows and is mentioned as the rationale for the laws governing relations among people in their communities or between different groups of people. When Maimonides discussed the entire array of relationships with non-Jews, ${ }^{28}$ he ended with the following words: "Our Sages commanded us to visit the gentiles when ill, to bury their dead in addition to the Jewish dead and support their poor in addition to the Jewish poor for the sake of peace. Behold, Psalms 145:9 states: 'God is good to all and His mercies extend over all His works' and Proverbs 3:17 states: 'The Torah's ways are pleasant ways and all its paths are peace"' (Laws of Kings, Chap. 10, Law 12).

Additional verses from Psalms and Proverbs add to the guidelines regarding acting for the sake of peace, a binding and ideal dimension. Thus, we are not talking here about compulsion, but rather about devotion to the qualities of $\mathrm{G}-\mathrm{d}$, who personifies mercy. The modern meaning of concern for a foreigner in general and a refugee in particular for the sake of peace is benign interest in and a helping hand for newcomers whoever they are regardless of their national or religious identity. Humanitarian activity is not limited to the boundaries of religion and nationality and requires an interest in the life and well-being of the refugee.

A similar position was expressed on several occasions by Rabbi Isser Yehuda Unterman, chief rabbi of Israel from 1964 to 1972. He declared that the basis of the rulings issued regarding "for the sake of peace" rely on the verse "and all His ways are peace," as from this we learn that in order to reach what we seek we have to take the paths of peace. That verse, Proverbs 3:17, states, "The Torah's ways are pleasant ways and all its paths are peace," and it notes the direction of the rulings, which are directed toward peace. "Thus one must not accord the title of observing Torah and mitzvot (commandments) to one who refuses to fulfill ethical obligations concerning one's fellow, such as the rulings for the sake of peace."29 ${ }^{29}$ matter what the religious and ethical justification for aiding refugees-the sanctity of life, caring for modern refugees as for the biblical slaves, or for the "sake of peace"-there is a need to prioritize activities so as to provide assistance to all who need it.

\section{Prioritizing Help and the Giving of Charity}

As indicated above, aid to refugees can take the form of refusing to return them to a situation of danger or providing material support to those who have fled danger, whether they have been given refuge or are still in another, third country. Directing economic resources outside the communal or national circle sometimes sparks opposition that derives from the wish to reserve the effort and resources to help those at home. Similarly, there is a suspicion that breaking the circle of recipients will weaken the link with the family or the people or that it might indicate weakness. Jewish ethical literature also deals with this conundrum.

\footnotetext{
${ }^{28}$ Based on Tosefta Gittin 3:18 (c. 200 CE) and repeated in the Babylonian Talmud, Gittin 61a.

${ }^{29}$ Isser Yehuda Unterman, "Ways of Peace and Their Definition," Morasha 1 (1971): 5-10 (in Hebrew).
} 
The Bible says, "and do not show favoritism to a poor person in a lawsuit" (Exodus 23:3). That is to say, there is a natural human tendency to have pity on the poor man and to sway the law in his favor against the strong, well-established litigant. Whoever does this, thinks that he is doing the right thing, but sometimes over-righteousness can disturb the desired balance. Thus, rules and principles have to be developed regarding the way to act toward the weak in society and on their behalf. On this matter there is an explicit instruction in the Talmud: "Rav Yosef taught: 'If you lend money to My people and the poor among you' (Exodus 22:24):-my people and Gentiles-my people first; poor and rich-the poor first; your poor and the poor of your town-your poor first; the poor of your town and the poor of another town-the poor of your town are first"' (Bava Metzia 71a).

I draw four conclusions from this: (1) the non-Jew, the foreigner, is also in the group entitled to the act of kindness of a loan (though his position in the list of priorities is low); (2) we must give priority for a donation to a poor Jewish person before a gift to someone from another people; (3) the proximity criterion determines that if the needy poor person is near you, the greater is your responsibility to help him; (4) there are various criteria for prioritizing help, and they have to be weighed one against the other: one has to compare the economic situation index (poor and rich) to the proximity index (your poor and the poor of your town)-and determine the deciding factor when the indices conflict.

Based on these considerations, Rabbi Moshe Sofer, one of the foremost rabbis in nineteenth-century Europe, said that one must give precedence to relatives, though not necessarily always. If those from afar are lacking the basic needs, then they come first. ${ }^{30}$ Thus, there is place for discretion, and in certain circumstances one can direct national resources to help refugees from other peoples that could be considered in great need, based on the explanation of the ways of peace and repairing the world, and they could take precedence over others in terms of charitable priorities. However, any deviation from the decreed priorities requires discretion and freedom from pressure.

\section{Reliability of the Messenger}

Another point that must be considered in assessing the ethics of directing aid to refugees is the reliability of the messengers who will transfer the aid from the donors to the refugees and the needy. There should be a distinction between aid and resettlement or asylum. Providing aid is not the same as allowing refugees to enter and resettle. International organizations are involved in both, but in the instance of aid, a donor country gives up nearly all control, whereas, in resettlement or asylum the receiving country of destination makes the decision about admission.

According to the Talmud, a condition of giving charity through messengers is whether they are reliable and professional. According to the Shulchan Aruch: "A person should not contribute to a charity fund unless he knows that the person in charge is trustworthy and knows how to act properly." 31

Against this background, there are those who want to preclude contributions to international charities owing to lack of clarity regarding the suitability of the messengers and the middlemen. This criterion has particular importance in view of the criticism that arises from time to time about the transparency in the actions of international aid organizations, which occasionally, despite their good intentions, end up with unfortunate results in conflict zones. Should nation-states develop more robust refugee responses because international organizations have not proven to be reliable messengers? Or is the need such that this question about the reliability of the messenger is less important because the international organizations are essential means for distributing aid to the world's refugees?

\footnotetext{
${ }^{30}$ Rabbi Moshe Sofer, "Yoreh De'ah Section 231," in Responsa Chatam Sofer (Jerusalem: Hamaor Press, 2010).

${ }^{31}$ Rabbi Joseph Karo, Shulchan Aruch, Yoreh De’ah 249:7 (Jerusalem: Hamaor Press, 2005).
} 
The reliability, professionalism, and loyalty of the aid workers and messengers are criteria that have to be considered in connection with any donation to charity to ensure that one's gift is used in a reasonable and feasible way.

\section{Conclusion}

Refugees who flee across the borders of various countries to save their lives today are human beings in distress and danger-not unlike slaves who ran away from their masters in the past, among them the Jews who fled their Egyptian masters. According to Jewish ethics, as derived from scripture and its commentaries over the last two thousand years, aid must be given to foreign refugees, even those who might be hostile. It must be done because it is one of the things that is right and proper for a person to do, because it is clearly in the realm of reciprocal responsibility between different nations and people, and because it engenders the attribute of mercy.

Cite this article: Rashi, Tsuriel. "Jewish Ethics Regarding Refugees: Ideology and Realization.” Journal of Law and Religion 37, no. 1 (2022): 153-166. https://doi.org/10.1017/jlr.2021.76. 